\title{
Exploring ways to increase public investments in agricultural water management and irrigation for improved agricultural productivity in Southern Africa
}

\author{
Charles Nhemachena ${ }^{1 *}$, Greenwell Matchaya', Sibusiso Nhlengethwa' and Charity R Nhemachena ${ }^{2}$ \\ 'International Water Management Institute, 141 Cresswell St, Weavind Park 0184, Pretoria, South Africa \\ ${ }^{2}$ Department of Finance and Economics, Graduate School of Business Leadership, University of South Africa, Midrand 1685, South Africa
}

\begin{abstract}
This paper explores ways to increase public investments in agricultural water management and irrigation for improved agricultural productivity in Southern Africa, with a specific focus on Malawi, Mozambique and Zambia. The analysis was based on a critical review of literature and assessment of the national agricultural investment plans and agricultural/water policies in the study countries. Despite the potential to improve agricultural productivity, irrigation does not currently play a significant role in Southern African agriculture. There have been efforts and formal commitments at the continental, regional and country levels to promote investments in agricultural water management and irrigation to improve and sustain agricultural productivity. However, despite these commitments, actual implementation has been a challenge and the first 5 years of national agricultural investment plans have passed or are now coming to an end without much progress having been made regarding actual investments. Lack of adequate resources and institutional capacity have been some of the challenges affecting implementation of the investment plans to meet commitments in sustainable land and water management. Overall, as countries plan for the second phase of the CAADP programme, there are opportunities to ensure that investments in agricultural water management and irrigation and complementary technologies are prioritised and allocated adequate resources for implementation.
\end{abstract}

Keywords: Agricultural water, irrigation, investment, productivity, Southern Africa

\section{INTRODUCTION}

African agricultural production systems and consumption patterns are vulnerable to weather, climate variability and change, global markets, and other shocks (African Union Commission, 2014; Challinor et al., 2014; Müller et al., 2011; Nhemachena et al., 2010; Niang et al., 2014). In addition, some of the priority issues facing the African agricultural sector include: addressing hunger and nutrition challenges; economic inequality and poverty particularly in rural areas; management of natural resources (especially land and water) and vulnerability to external shocks (African Union Commission, 2014; Nhemachena et al., 2018; Niang et al., 2014; SADC, 2016). The 2014 Malabo Declaration, adopted by the African Heads of State and Government, reaffirmed the importance of agriculture in achieving shared prosperity and improved livelihoods through accelerated agricultural growth and transformation (African Union Commission, 2014). In Southern Africa, the agricultural sector provides livelihoods (directly and indirectly) to over $60 \%$ of the rural population and contributes an average of $17 \%$ to the region's gross domestic product (GDP), demonstrating the importance of the performance of the sector to regional economic growth and food security (SADC, 2014; SADC, 2015). However, over $90 \%$ of agricultural activities are mainly under smallholder systems and rainfed. In addition, low agricultural productivity and food insecurity remain critical challenges for millions in Southern Africa. Also, the performance of the regional agriculture sector has been insufficient to make significance contributions to food security and other

\footnotetext{
To whom all correspondence should be addressed.

e-mail: C.Nhemachena@cgiar.org; CNhemachena@gmail.com Received 1 June 2017; accepted in revised form 13 June 2018
}

developmental goals in the region (SADC, 2016). Therefore, the development and performance of the agricultural sector remains central to efforts focused on promoting socioeconomic development and reduction of poverty, food and nutrition insecurity in the region.

One of the priority resolutions of the 2014 Malabo Declaration and the Africa Union Commission Joint Conference of Ministers of Agriculture, Rural Development, Fisheries and Aquaculture, to contribute to attaining accelerated growth of agricultural production and productivity, was to increase investments in efficient and effective water management systems (African Union Commission, 2014; African Union Commission, 2014). The Comprehensive Africa Agriculture Development Programme (CAADP) Pillar 1 on sustainable land and water management provides a continental resolve in Africa by African heads of state and respective ministries to increase investments in agricultural water management (AUC and NEPAD, 2009). The 2014 Malabo Declaration re-emphasised this commitment to support accelerated agriculture-led growth and development in Africa (African Union Commission, 2014). At the regional level, the Southern African Development Community (SADC) member states committed in the Regional Strategic Development Plan (RISDP) to increase investments in arable agricultural land under irrigation from $3.5 \%$ to $7 \%$ (SADC, 2003). In addition, member states have various interventions focused on enhancing investments in agricultural water management. These efforts are aimed at advancing investments in agricultural water management and irrigation to improve and sustain agricultural productivity in Southern Africa and Sub-Saharan Africa.

However, despite its potential to improve productivity (You et al., 2011) and a number of initiatives indicated above, irrigation does not currently play a significant role in Southern 
African agriculture, as less than $5 \%$ of the arable land is under irrigation (Chilonda et al., 2013). Therefore, the objective of this paper was to explore the current challenges and opportunities for increasing public investments in agricultural water management for improved agricultural productivity in Southern Africa. Investments in agricultural water management are defined as expenditures (public or private), which facilitate economic production and are usually distinguished from recurrent expenditures on operation and maintenance of infrastructure or salaries (Turral et al., 2010). Following this concept, public investment in agricultural water management encompasses 'public expenditures in irrigation and drainage development, modernisation, institutional reform, improved governance, capacity building, management improvement, creation of farmer organisations, and regulatory oversight, as well as farmers' investment in joint facilities, wells, and on-farm water storage and irrigation equipment' (Molden, 2007 p. 364). The analyses focus on three Southern African countries (Malawi, Mozambique and Zambia) that have finalised their national agricultural investment plans as part of the implementation of the Comprehensive Africa Agriculture Development Programme. Given that commitments to increase the area under irrigation in the region remain largely unfulfilled, it is critical to unpack the existing challenges and opportunities focused on enhancing public investments in agricultural water management and irrigation.

\section{IMPORTANCE OF INVESTMENTS IN AGRICULTURAL WATER AND IRRIGATION FOR ENHANCED AGRICULTURAL PRODUCTIVITY}

Despite questions raised on the performance of investments in irrigation in the past, there is evidence that investments in irrigated areas contributed to significant agricultural production growth, food security and poverty reduction in the target areas (De Fraiture et al., 2010; Fan et al., 2000; Huang et al., 2006; Lipton et al., 2003; Turral et al., 2010). For example, Domenech and Ringler (2013) reported that the impact of irrigation on yield can be as much as a $150 \%$ increase in maize and other crops in Africa, because the base yield levels are low. In a separate example, estimates from Siebert and Döll (2010) showed that irrigation contributed to increases in global cereal yields averaging $4.4 \mathrm{t} /$ ha compared to $2.7 \mathrm{t} /$ ha produced under rainfed conditions. Also, the Comprehensive Assessment of Water Management in Agriculture reported that management of agricultural water resources has been instrumental in contributing to increased food production, food security and rural incomes across the wold (Comprehensive Assessment of Water Management in Agriculture (CA), 2007; Turral et al., 2010). In addition, investments in agricultural water management could potentially benefit about $58 \%$ of the rural population in Sub-Saharan Africa (Faurès and Santini, 2008).

The contribution of investments in irrigation adapted to changing socio-economic and environmental conditions is expected to remain critical for future food production across the world (Magistro et al., 2007; Turral et al., 2010; World Bank, 2007; You et al., 2011). You et al. (2011) found significant profitable irrigation potential for small-scale and large-scale systems in Africa. They estimated the large-scale irrigation potential at 15 million ha and a complementary small-scale component of 7 million ha. This means that more efforts are required to ensure investments in irrigation are aligned with developmental priorities/goals/policies of the countries (Turral et al., 2010), including ensuring that changes in water scarcity and quality are integrated in the planning and implementation of irrigation investments. In addition, there is a need for improved knowledge of niche areas that have greatest potential for irrigation, as part of efforts to expand the area under irrigation in Africa (You et al., 2011).

Investments in irrigation are also critical as an adaptation strategy to climate variability (both seasonal and annual). Irrigation enables the smoothing out of potential impacts of climate change variability (seasonal and inter-annual) on agricultural performance (Hassan and Nhemachena, 2008; Mendelsohn and Dinar, 2003; Nhemachena, 2009; Turral et al., 2010). Despite the potential of irrigation to address impacts of climate change and variability, the sustainability of irrigation investments is also threatened by water scarcity due to impacts of climate change on water resources (De Fraiture et al., 2010; Turral et al., 2010). For example, predicated changes in climate and related variability of climatic conditions in Southern Africa are expected to result in increased water scarcity (Field et al., 2014) affecting the availability of water for irrigation. Increased water scarcity coupled with increased demand for water by crops due to changes in rainfall and temperature would require strategic investments in agricultural water management and irrigation to improve and sustain agricultural productivity in the region. This means that there is need to have comprehensive irrigation investment planning beyond focusing on increasing areas under irrigation. For example, public irrigation investment plans should address issues of sustainable water use and efficiency in irrigation systems. In addition, measures and investment centred around water storage, either in dams or underground, will be critical to sustain irrigation investments and cropping systems in droughts and dry seasons (De Fraiture et al., 2010; Turral et al., 2010).

Furthermore, irrigation remains one of the many deficient productivity-improving capital investments and technological inputs in Africa, together with fertilisers, improved seed delivery systems, post-harvest processing facilities, and access to markets (Svendsen et al., 2009; You et al., 2011). Therefore, public investments in irrigation in Southern Africa would require complementary investments in productivityenhancing factors such as use of fertilisers, and hybrid seeds. In achieving the full potential of agricultural water and irrigation investments, concerted efforts would be required not only in direct investments in irrigation and associated complementary technologies but also in building institutions, providing training and market development (Svendsen et al., 2009; You et al., 2011).

Overall, with more than $70 \%$ of Africa's poor population living in rural areas and mostly relying on agriculture for their livelihoods, the development of the agricultural sector remains critical for addressing hunger and poverty on the continent (You et al., 2011). Despite its potential to improve productivity (You et al., 2011), irrigation does not currently play a significant role in Southern African agriculture. This means that investments in agricultural water management and irrigation remain critical for improving and sustaining agricultural productivity and reducing poverty in Southern Africa, as in the rest of Africa.

\section{METHODS}

The analysis of current challenges and opportunities was based on a critical review of literature and assessment of the national agricultural investment plans and agricultural/ water policies in the study countries. We reviewed investment plans and agricultural/water policies of the selected countries to identify current gaps, and challenges faced by the respective governments in their endeavours to support irrigation development. Data on irrigation potential 
and area equipped for irrigation in Southern Africa were gathered from the FAO's Aquastat website. We augmented discussions of findings with review of published literature on agricultural water management and irrigation, particularly in Africa and other developing countries. We then discuss an enabling environment for investments in agricultural water management and irrigation in the three focus countries (Malawi, Mozambique and Zambia). This is followed by a discussion of agricultural water management and irrigation plans in national agricultural investment plans of Malawi, Mozambique and Zambia. The last part discusses overall challenges and opportunities for investments in agricultural water management and irrigation in Southern Africa to improve agricultural productivity.

\section{RESULTS AND DISCUSSION}

\section{Enabling environment for investments in agricultural water management and irrigation in Malawi, Mozambique and Zambia}

The implementation of investments in agricultural water management and irrigation in Southern Africa, as indicated above, is guided by continental, regional and national frameworks. Specifically at the continental level, the resolutions of the 2014 Malabo Declaration especially focus on efforts to increase investments in efficient and effective water management systems (African Union Commission, 2014; African Union Commission, 2014). In addition, the Comprehensive Africa Agriculture Development Programme Pillar 1 on land and water management provides a continental resolve in Africa by African heads of state and respective ministries to increase investments in agricultural water management (AUC and NEPAD, 2009). At the regional level, the SADC Regional Indicative Strategic Development Plan and SADC water policy provide the enabling framework for implementation of investments in agricultural water management and irrigation. In addition, member countries have various policies and strategic plans that address agricultural water management and irrigation in various ways. Table 1 summarises key policy and strategic planning documents that provide an enabling framework for investment plans for agricultural water management and irrigation in each of the focus countries: Malawi, Mozambique and Zambia.

The Malawi Growth and Development Strategy (MGDS) represents a policy shift from social consumption to sustainable development and infrastructure development. The Ministry of Agriculture and Food Security formulated the National Agricultural Policy Framework (NAPF) to harmonise agricultural policies so that they are aligned to the agriculture

\begin{tabular}{|c|c|c|}
\hline \multicolumn{3}{|c|}{$\begin{array}{c}\text { TABLE } 1 \\
\text { Summary of national policy and strategic plans in Malawi, Mozambique and Zambia }\end{array}$} \\
\hline $\begin{array}{l}\text { National government } \\
\text { strategies/plans }\end{array}$ & $\begin{array}{l}\text { Supporting policies for agricultural water } \\
\text { infrastructure investment }\end{array}$ & Implementing ministries \\
\hline \multicolumn{3}{|l|}{ Malawi } \\
\hline \multirow{7}{*}{$\begin{array}{l}\text { Malawi Growth } \\
\text { Development Strategy } \\
\text { MGDS) }\end{array}$} & National Agriculture Policy Framework (NAPF) 2006 & Ministry of Agriculture and Food Security \\
\hline & Agriculture Sector Wide Approach (ASWAp) 2010 & Ministry of Agriculture and Food Security \\
\hline & $\begin{array}{l}\text { National Irrigation Policy and Development } \\
\text { Strategy (2000) }\end{array}$ & Ministry of Irrigation and Water Development \\
\hline & Water Policy (1996) & Ministry of Irrigation and Water Development \\
\hline & $\begin{array}{l}\text { Water Resources Management Policy and Strategy } \\
(2000)\end{array}$ & Ministry of Irrigation and Water Development \\
\hline & Water Resources Act No. 2 of 2013 & Ministry of Irrigation and Water Development \\
\hline & Irrigation Act (2001) & Ministry of Irrigation and Water Development \\
\hline \multicolumn{3}{|l|}{ Mozambique } \\
\hline \multirow[t]{6}{*}{$\begin{array}{l}\text { Government Five-Year } \\
\text { Programme }\end{array}$} & $\begin{array}{l}\text { Strategic Development Plan for the Agricultural } \\
\text { Sector (PEDSA) } 2010 \text { - } 2019\end{array}$ & Ministry of Agriculture \\
\hline & $\begin{array}{l}\text { National Investment Plan for the Agricultural } \\
\text { Sector (PNISA) } 2012\end{array}$ & Ministry of Agriculture \\
\hline & Agricultural Policy and Implementation Strategy & Ministry of Agriculture \\
\hline & Water Law (1991) & Minister of the Sea, Inland Waters and Fisheries \\
\hline & National Water Policy (1995) & Minister of the Sea, Inland Waters and Fisheries \\
\hline & $\begin{array}{l}\text { National Irrigation Policy and its Implementation } \\
\text { Strategy (2002) }\end{array}$ & Minister of the Sea, Inland Waters and Fisheries \\
\hline \multicolumn{3}{|l|}{ Zambia } \\
\hline \multirow{4}{*}{$\begin{array}{l}\text { The Sixth National } \\
\text { Development Plan } \\
\text { (SNDP) }\end{array}$} & National Agricultural Policy (NAP) 2012 & Ministry of Agriculture and Livestock \\
\hline & National Agricultural Investment Plan 2014 - 2018 & Ministry of Agriculture and Livestock \\
\hline & Water Policy 1994 & Ministry of Energy and Water Development \\
\hline & National Irrigation Plan (NIP) (2005) & Ministry of Energy and Water Development \\
\hline
\end{tabular}


component of the MGDS (Government of Malawi, 2017). Both the MGDS and the NAPF are aligned to the regional and continental frameworks through the National Agricultural Investment Plan, also referred to as the Agricultural Sector Wide Approach (ASWAp) (Government of Malawi, 2011; 2017). However, there are three implementing ministries (Ministry of Agriculture, Ministry of Irrigation and Water Development and the Ministry of Local Government and Rural Development) which in turn are custodians of the different policies that may affect the agricultural water infrastructure investment. The challenge is how to coordinate planning and implementation of investments related to agricultural water management and irrigation from the different ministries. In addition, another critical challenge has been to raise adequate resources to implement and roll out planned activities. As a result, not all targets have been met and one of the areas that still require substantial investment is agricultural water management.

In the case of Mozambique, the Government Five-Year Programme (PQG) governs and outlines the development of basic infrastructure in the agriculture sector. In addition to the PQG, the government has the Action Plan for the Reduction of Poverty (PARP) (Government of Mozambique, 2010). This strategy operationalises the recommendations of the PQG concerning actions against poverty. The PARP is a key link in the National Planning System (SNP) and is aligned with other important documents, such as Agenda 2025 (Government of Mozambique, 2011). The Ministry of Agriculture instigated the Agricultural Policy and Implementation Strategy (PAEI), the Strategic Plan for the Development of the Agricultural Sector 2011-2015 (PEDSA), the Rural Development Strategy (EDR), and the Food and Nutritional Security Strategy II (ESAN II, 2008-2015), while the Ministry of Fisheries produced the following: the Fishery Policy and Implementation Strategy (PPEI), the Fishery Master Plan 2010-2019 (PDP), and the Development Plan for Small Scale Aquaculture 2009-2013 (PDAPQ). There are so many policies backing agricultural water infrastructure investments but they're not coordinated nor governed by the same ministry. Again, as in Malawi, in Mozambique the agriculture, land, fisheries and water fall under four different ministries making the coordination of the implementation of the agricultural water infrastructure investments quite difficult to plan, implement and monitor. The main challenge for Mozambique is that some of the policies' planned time periods have come to an end. However, although efforts are in place to institute new ones or extended phases, the country also faces the challenge of ensuring implementation of all the plans. One of the critical challenges has been institutional capacity and availability of resources.

In Zambia, the Sixth National Development Plan (SNDP) is currently the major guiding document of the agriculture sector (Government of Zambia, 2013). A subset of the SNDP is the National Agriculture Policy (NAP), which focuses on ensuring national household food security through all-year-round production and post-harvest management of food stuffs. The Government of the Republic of Zambia endorsed the CAADP Compact which is aimed at strengthening, supporting and facilitating effective implementation of the NAP and the Vision 2030 through 5-year phases of the National Development Plans aligned to the CAADP Pillars. The Zambian CAADP Compact stresses that there is a need to develop a National Water Supply and Sanitation Policy. It also highlights the need to develop strategies for increasing investments in the irrigation sub-sector. The coordination of the agricultural water infrastructure investments in Zambia fall under three ministries: the Ministry of Agriculture and Livestock, Ministry of Energy and Water Development and the Ministry of Community Development, Mother and Child Health.

\section{Agricultural water management and irrigation investment plans in Malawi, Mozambique and Zambia}

Table 2 presents the summary of agricultural water management and irrigation plans for Malawi, Mozambique and Zambia. For Malawi, the ASWAp's priority investment area is on sustainable agricultural land and water management. In order to mitigate weather variability and climate change, Malawi instigated the Greenbelt Initiative which is aimed at increasing water use efficiency and strengthening irrigation potential. However, under this initiative these investments are only justified for high-value crops for local and export markets. The estimated budget for the investment in the sustainable agricultural water management component was US\$ 583670000 over the course of 5 years (2010-2014).

The National Agricultural Investment Plan of Mozambique (PNISA) outlines the investments in agricultural water infrastructure in the three subsectors (a) crop production (includes an irrigation programme), (b) aquaculture and (c) livestock (Government of Mozambique, 2014). The objectives of the PNISA under crop production are outlined by the Food Crop Programme and the Agricultural Irrigation Programme. The Agricultural Irrigation Programme seeks to develop irrigation infrastructure using two approaches: (a) small (less than $200 \mathrm{ha}$ ) and (b) medium/large (equal/larger than $200 \mathrm{ha}$ ) irrigation areas. The strategic vision is for the development of infrastructure that would be multi-purpose and also be used for livestock and aquaculture. The three challenges addressed by the irrigation programme are: training and operationalising public irrigation services; expanding the irrigated area by at least 50 000 ha and; raising the level of utilisation of irrigation networks from the current $60 \%$ to $80 \%$. The investments are geared towards rehabilitation and construction of hydro-agricultural infrastructure, promotion of low-cost irrigation and conservation of surface and ground water resources for irrigation in drier areas. MT 24285429 (for 5 years) was set aside for this programme.

Zambia's National Agriculture Investment Plan has four main investment programmes: (a) sustainable natural resources management, (b) agricultural production and productivity improvement, (c) market access, and (d) food and nutrition security and disaster risk management (Government of Zambia, 2014). The water investment component is in the first programme and this programme is aimed at ensuring efficient water-use and irrigation. The total budget allocated for the sustainable natural resources management programme over 5 years (2014-2018) is USD280 800000 (Government of Zambia, 2014). The outcome indicators for this component include: (a) a $20 \%$ increase in the number of farmers with access to irrigation infrastructure for high-value crops and, (b) an increase in the area under irrigation by 188000 ha.

Overall, the above review of the agricultural water management and irrigation investment allocations in the national agricultural investment plans of the three countries indicate national commitments to increase investments in these areas. However, despite these commitments, actual implementation has been a challenge and the first 5 years have passed without much progress. Lack of adequate financial resources and institutional capacity have been some of the constraints affecting implementation of the investment plans. Under the CAADP Programme national governments are 
TABLE 2

Summary of agricultural water management and irrigation plans in national investment plans (Source: Authors' compilation based on data from National Agriculture Investment Plans of the three countries)

\begin{tabular}{|c|c|c|c|}
\hline $\begin{array}{l}\text { National agricultural } \\
\text { investment plan }\end{array}$ & $\begin{array}{l}\text { Investment focus area on } \\
\text { agricultural water }\end{array}$ & Investment components of the focused area & Investment value \\
\hline \multicolumn{4}{|l|}{ Malawi } \\
\hline $\begin{array}{l}\text { Agriculture Sector Wide } \\
\text { Approach (ASWAp) } \\
\text { 2011-2016 }\end{array}$ & $\begin{array}{l}\text { Sustainable Agricultural } \\
\text { Land and Water } \\
\text { management }\end{array}$ & $\begin{array}{l}\text { Promoting increased use of irrigation } \\
\text { Promoting simple rainwater harvesting and storage } \\
\text { systems including the construction of dams } \\
\text { Rehabilitating old and developing new small- to } \\
\text { medium-scale irrigation schemes for high-value } \\
\text { commodities (to expand the area under irrigation } \\
\text { from } 20000 \text { ha to } 40000 \text { ha) for the period 2011-2016 } \\
\text { Involving WUAs in sustainable water management, } \\
\text { use efficient irrigation technologies }\end{array}$ & USD 583670000 \\
\hline \multicolumn{4}{|l|}{ Mozambique } \\
\hline $\begin{array}{l}\text { National Investment } \\
\text { Plan for the } \\
\text { Agricultural Sector } \\
\text { (PNISA) (2014-2018) }\end{array}$ & $\begin{array}{l}\text { Production and } \\
\text { productivity }\end{array}$ & $\begin{array}{l}\text { Promote the use of improved technologies including } \\
\text { low-cost irrigation } \\
\text { Training and operationalise public irrigation services } \\
\text { Expand the irrigated area by at least } 50000 \text { ha } \\
\text { Raise the level of utilisation of irrigation networks } \\
\text { from the current } 60 \% \text { to } 80 \%\end{array}$ & MT 35573729 \\
\hline \multicolumn{4}{|l|}{ Zambia } \\
\hline $\begin{array}{l}\text { National Agricultural } \\
\text { Investment Plan } \\
(2014-2018)\end{array}$ & $\begin{array}{l}\text { Sustainable Natural } \\
\text { Resources Management }\end{array}$ & $\begin{array}{l}20 \% \text { increase in the number of farmers with access to } \\
\text { irrigation infrastructure for high value crops } \\
\text { An increase in the area under irrigation by } 188000 \text { ha } \\
\text { Strengthen a total of } 750 \text { water user associations } \\
\text { and rehabilitating and constructing new irrigation } \\
\text { schemes } \\
\text { Multi-purpose dams ( } 45 \text { small and } 2 \text { large) as well as } \\
50 \text { weirs will be constructed } \\
5000 \text { pumps and } 1900 \text { renewable energy pumps for } \\
5000 \text { ha }\end{array}$ & USD 169250000 \\
\hline
\end{tabular}

expected to raise the bulk of the resources domestically with the rest coming from international donors and other sources. However, most of the countries in Southern Africa have not been able to raise enough domestic resources to drive implementation of national agricultural investment plans, particularly those focusing on agricultural water management and irrigation.

\section{Opportunities and challenges for investments in agricultural water management and irrigation in Southern Africa}

The share of irrigation potential equipped for irrigation ranges from as low as 2\% in Angola to 72\% in Madagascar and the average for the region is $30 \%$ (FAO, 2016). Table 3 summarises the area under irrigation in Southern Africa. Most of the Southern African countries are still to meet the commitments of both CAADP and the RSIDP. Based on the data only Madagascar, Mauritius, South Africa, and Swaziland have areas equipped for irrigation above the CAADP and RISDP commitments. The rest of the countries recorded levels of area equipped for irrigation of less than $5 \%$ of their arable land with values close to zero, for example, in Botswana, Lesotho and Namibia. This means that, despite the potential for irrigation in the region, there is a need for more efforts to increase

TABLE 3

Summary of area equipped with irrigation in Southern Africa (\% or arable land)

(Source: Authors compilation based on data from FAOSTAT (FAO 2017))

\begin{tabular}{|l|r|r|r|c|}
\hline Country & $\mathbf{2 0 0 0}$ & $\mathbf{2 0 0 5}$ & $\mathbf{2 0 1 0}$ & $\mathbf{2 0 1 5}$ \\
\hline Angola & 2.7 & 2.6 & 2.1 & 1.8 \\
\hline Botswana & 0.4 & 0.6 & 0.8 & 0.6 \\
\hline Congo, Dem. Rep. & 0.2 & 0.2 & 0.2 & 0.2 \\
\hline Lesotho & 0.9 & 0.9 & 0.9 & 1.1 \\
\hline Madagascar & 37.4 & 36.2 & 31.0 & 31.0 \\
\hline Malawi & 2.0 & 2.2 & 2.0 & 1.9 \\
\hline Mauritius & 22.2 & 24.7 & 25.0 & 25.7 \\
\hline Mozambique & 2.9 & 2.4 & 2.1 & 2.1 \\
\hline Namibia & 0.9 & 1.0 & 1.0 & 1.0 \\
\hline South Africa & 10.8 & 11.5 & 12.3 & 13.4 \\
\hline Swaziland & 28.1 & 28.1 & 28.6 & 28.6 \\
\hline Tanzania & 1.9 & 2.6 & 2.9 & 2.7 \\
\hline Zambia & 4.8 & 5.7 & 4.6 & 4.1 \\
\hline Zimbabwe & 4.8 & 4.5 & 4.4 & 4.4 \\
\hline
\end{tabular}


investments in agricultural water management and irrigation as part of efforts to improve agricultural productivity. Despite the potential for irrigation to improve agricultural productivity in Southern Africa, the challenge for planning, implementation and evaluation of such investments is how to integrate the changing socio-economic and environmental factors. For example, it is critical that the investments are strategically targeted to ensure that they address a range of factors that include alignment with agricultural priorities, higher socio-economic returns, and environmental impacts (Inocencio et al., 2007; Turral et al., 2010). Furthermore, despite the great potential and opportunities for investments in irrigation in Southern Africa, as in other parts of Africa (Peacock et al., 2007; You et al., 2011), the other challenge for decision makers is how to design and implement innovative approaches for agricultural water management and irrigation investments to ensure that the expected outcomes are realised and attractive (Peacock et al., 2007).

Another critical challenge is how to target and prioritise agricultural water management and irrigation investments for the best outcomes. Targeting of high-potential irrigated and rainfed areas has the potential to generate the highest productivity returns as they generate high agricultural output and economic growth at lower costs than in marginal areas (Fan et al., 2000; Turral et al, 2010). However, public investments in irrigation targeted for marginal areas has been found to generate higher marginal returns compared to investments in high-potential irrigated and rainfed areas (Fan et al., 2000). The challenge for Southern African countries is creating a balance between investments in these high potential areas and in marginal areas, where most of the rural poor reside and are in dire need of efforts to improve the productivity of their lands, which are mainly rainfed. Efforts to drive inclusive agricultural growth and development within the Malabo Declaration mean that considerable efforts should be put into designing public investments in irrigation that allow the rural subsistence farmers to actively benefit. The analysis of the current national investment plans for the selected countries in the region, however, does not provide detailed investment plans specifically targeting these smallholder farmers in marginal lands. In addition, there is no explicit layout of public investments in irrigation to support agricultural growth and development. The expectation is that the ongoing revisions of the national agricultural investment plans to integrate Malabo Declaration commitments would explicitly consider the need to invest in irrigation to support smallholder agricultural production located in marginal areas.

Compared to the past large-scale irrigation approaches implemented based on top-down approaches, investment plans in Southern Africa should emphasise bottom-up approaches where beneficiaries are actively involved. Bottom-up approaches that address cultural, social and environmental aspects are critical for successful planning and implementation of irrigation investments and associated technologies (Van Schilfgaarde, 1994). In addition, irrigation policies in SubSaharan Africa prioritise investments in small irrigation schemes to enhance agricultural productivity and food security achievement and integration of cultural traditions (Faures et al., 2007). Successful implementation of public investments in agricultural water management and irrigation in Southern Africa, as in the rest of Sub-Saharan Africa, would also need to learn from past investments and ensure that success factors are strengthened and failures are avoided (García-Bolaños et al., 2011). Given the scarcity and competing needs for resources, public investments in irrigation should be able to produce higher social benefits/returns through, for example, productivity growth and poverty reduction (Fan et al., 2000) to be economically justified.

\section{CONCLUSIONS}

The objective of this paper was to explore the current challenges and opportunities for increasing public investments in agricultural water and irrigation for improved agricultural productivity in Southern Africa, focusing on Malawi, Mozambique and Zambia. The analysis of current challenges and opportunities was based on a critical review of literature and assessment of the national agricultural investment plans and agricultural/ water policies in the study countries. Some of the challenges for investments in agricultural water management and irrigation in Southern Africa include: acquiring adequate resources for increasing current investment levels to meet continental, regional and country-level commitments to sustainable land and water management. In addition to support investments in agricultural water management and irrigation, substantial efforts are required to invest in complementary capital and technological inputs, such as fertilisers, improved seed delivery systems, post-harvest processing facilities, access to markets, etc. To ensure achievement of the full potential of these investments, countries would need to direct resources to invest in complementary technological inputs as well as building institutions, providing training and market development.

Changes in climate and variability also pose challenges for plans to increase the area under irrigation in Southern Africa. It is therefore critical that investment planning looks beyond expanding the area under irrigation to address other issues such as sustainable water use, efficiency in irrigation systems and investments in water storage to sustain irrigation investments and cropping systems in droughts and dry seasons. Another challenge is the need to gather improved knowledge of niche areas that have greatest potential for irrigation needs. Despite the great potential for investments in irrigation in Southern Africa, as in other parts of Africa the other challenge for decision makers is how to design and implement innovative approaches to ensure that the expected outcomes are realised and attractive. The challenge for Southern African countries is creating a balance between investments in these high-potential areas and in marginal areas, where most of the rural poor reside. Considerable efforts should be put in designing public investments in irrigation that allows the rural subsistence farmers to actively benefit.

Overall, the above review of the agricultural water management and irrigation investment allocations in the national agricultural investment plans of the three countries indicate national commitments to increase investments in these areas. However, despite these commitments, actual implementation has been a challenge and the first 5 years have passed or are now coming to an end without much progress made regarding actual investments. Lack of adequate financial resources and institutional capacity have been some of the constraints affecting implementation of the investment plans. Under the CAADP Programme national governments are expected to raise the bulk of the resources domestically with the rest coming from international donors and other sources. However, most of the countries in Southern Africa have not been able to raise enough domestic resources to drive implementation of national agricultural investment plans, particularly focusing on agricultural water management and irrigation. 


\section{REFERENCES}

AFRICAN UNION COMMISSION (2014) Implementation strategy and roadmap to achieve the 2025 vision on CAADP. African Union Commission, Addis Ababa, Ethiopia.

AFRICAN UNION COMMISSION (2014) Malabo declaration on accelerated agricultural growth and transformation for shared prosperity and improved livelihoods. Africa Union Commission, Addis Ababa.

AFRICAN UNION COMMISSION (2014) Resolutions of the AU Joint Conference of Ministers of Agriculture, Rural Development, Fisheries and Aquaculture. African Union Commission, Addis Ababa, Ethiopia.

AUC and NEPAD (2009) Sustainable land and water management. The CAADP Pillar I Framework. "Tool" for use by countries in mainstreaming and upscaling of sustainable land and water management in Africa's agriculture and rural development agenda. NEPAD, Midrand, South Africa.

CHALLINOR AJ, WATSON J, LOBELL D, HOWDEN S, SMITH D and CHHETRI N (2014) A meta-analysis of crop yield under climate change and adaptation. Nat. Clim. Change 4 (4) 287. https:// doi.org/10.1038/nclimate2153

CHILONDA P, MATCHAYA G, CHIWAULA I, KAMBEWA P, MUSABA E and MANYAMBA C ( 2013) Agricultural growth trends and outlook for Southern Africa: Enhancing regional food security throughincreased agricultural productivity. ReSAKSS-SA Annual Trends and Outlook Report 2011. International Food Policy Research Institute (IFPRI) and the International Water Management Institute, Washington DC, Colombo.

COMPREHENSIVE ASSESSMENT OF WATER MANAGEMENT IN AGRICULTURE (CA) (2007) Water for Food, Water for Life: $a$ Comprehensive Assessment of Water Management in Agriculture. Earthscan and International Water Management Institute, London and Colombo.

DE FRAITURE C, MOLDEN D and WICHELNS D (2010) Investing in water for food, ecosystems, and livelihoods: An overview of the comprehensive assessment of water management in agriculture. Agric. Water Manage. 97 (4) 495-501. https://doi.org/10.1016/j. agwat.2009.08.015

DOMENECH L and RINGLER C (2013) The Impact of Irrigation on Nutrition, Health, and Gender A Review Paper with Insights for Africa south of the Sahara. IFPRI Discussion Paper 01259. Environment and Production Technology Division, International Food Policy Research Institute, Washington DC, USA.

FAN S, HAZELL P and HAQUE T (2000) Targeting public investments by agro-ecological zone to achieve growth and poverty alleviation goals in rural India. Food Polic. 25 (4) 411-428. https://doi. org/10.1016/S0306-9192(00)00019-1

FAO (2016) AQUASTAT Database. Food and Agriculture Organization of the United Nations (FAO). URL: http://www.fao.org/nr/water/ aquastat/data/query/index.html?lang=en (Accessed 13 June 2016)

FAO (2017) FAOSTAT Database. Food and Agriculture Organization of the United Nations (FAO). URL: http://www.fao.org/faostat/ en/\#data. (Accessed 31 May 2017).

FAURÈS J-M and SANTINI G (2008) Water and the rural poor: interventions for improving livelihoods in sub-Saharan Africa. International Fund for Agricultural Development (IFAD), Rome, Italy.

FAURES J-M, SVENDSEN M, TURRAL H, BERKHOFF J, BHATTARAI M, CALIZ A, DARGHOUTH S, DOUKKALI M, EL-KADY M and FACON T (2007) Reinventing irrigation. International Water Management Institute, Colombo, Sri Lanka.

FIELD CB, BARROS VR, MACH K and MASTRANDREA M (2014) Climate change 2014: Impacts, Adaptation, and Vulnerability. Cambridge University Press, Cambridge. https://doi.org/10.1017/ CBO9781107415379

GARCÍA-BOLAÑOS M, BORGIA C, POBLADOR N, DIA M, SEYID OMV and MATEOS L (2011) Performance assessment of small irrigation schemes along the Mauritanian banks of the Senegal River. Agric. Water Manage. 98 (7) 1141-1152. https://doi. org/10.1016/j.agwat.2011.02.008

GOVERNMENT OF MALAWI (2011) Agriculture Sector Wide Approach (ASWAp) 2011-2016. Government of Malawi, Lilongwe, Malawi.
GOVERNMENT OF MALAWI (2017) The Malawi Growth and Development Strategy (MGDS) III. Government of Malawi, Ministry of Economic Planning \& Development, Lilongwe, Malawi. GOVERNMENT OF MOZAMBIQUE (2010) Five-year Plan of the Government (2011-2014). Government of Mozambique, Maputo, Mozambique

GOVERNMENT OF MOZAMBIQUE (2011) Action Plan for the Reduction of Poverty (PARP) 2011-2014. Government of Mozambique, Maputo, Mozambique.

GOVERNMENT OF MOZAMBIQUE (2014) National Investment Plan for the Agricultural Sector (PNISA) (2014-2018). Government of Mozambique, Maputo, Mozambique.

GOVERNMENT OF ZAMBIA (2013) Revised sixth National Development Plan 2013-2016. Government of Zambia, Lusaka, Zambia.

GOVERNMENT OF ZAMBIA (2014) National Agriculture Investment Plan (2014-2018). Government of Zambia, Lusaka, Zambia.

HASSAN R and NHEMACHENA C (2008) Determinants of African farmers' strategies for adapting to climate change: Multinomial choice analysis. Afr. J. Agric. Resour. Econ. 2 (1) 83-104.

HUANG Q, ROZELLE S, LOHMAR B, HUANG J and WANG J (2006) Irrigation, agricultural performance and poverty reduction in China. Food Polic. 31 (1) 30-52. https://doi.org/10.1016/j. foodpol.2005.06.004

INOCENCIO A, KIKUCHI M, TONOSAKI M, MARUYAMA A, MERREY D, SALLY H and DE JONG I (2007) Costs and performance of irrigation projects: A comparison of sub-Saharan Africa and other developing regions. IWMI, Colombo. $71 \mathrm{pp}$.

LIPTON M, LITCHFIELD J and FAURĖS J-M (2003) The effects of irrigation on poverty: a framework for analysis. Water Polic. 5 (5-6) 413-427. https://doi.org/10.2166/wp.2003.0026

MAGISTRO J, ROBERTS M, HAGGBLADE S, KRAMER F, POLAK P, WEIGHT E and YODER R (2007) A model for pro-poor wealth creation through small-plot irrigation and market linkages. Irrig. Drain. 56 (2-3) 321-334. https://doi.org/10.1002/ird.300

MENDELSOHN R and DINAR A (2003) Climate, water, and agriculture. Land Econ. 79 (3) 328-341. https://doi. $\operatorname{org} / 10.2307 / 3147020$

MOLDEN D (2007) Water for Food, Water for Life. A Comprehensive Assessment of Water Management in Agriculture. Earthscan, London; International Water Management Institute, Colombo.

MÜLLER C, CRAMER W, HARE WL and LOTZE-CAMPEN H (2011) Climate change risks for African agriculture. Proc. Natl Acad. Sci. 108 (11) 4313-4315. https://doi.org/10.1073/pnas.1015078108

NHEMACHENA C (2009) Agriculture and future climate dynamics in Africa: Impacts and adaptation options. PhD Thesis. University of Pretoria.

NHEMACHENA C, HASSAN R and KURUKULASURIYA P (2010) Measuring the economic impact of climate change on African agricultural production systems. Clim. Change Econ. 1 (1) 33-55. https://doi.org/10.1142/S2010007810000066

NHEMACHENA C, MATCHAYA G, NHEMACHENA CR, KARUAIHE S, MUCHARA B and NHLENGETHWA S (2018) Measuring baseline agriculture-related sustainable development goals index for Southern Africa. Sustainability 10 (3) 849. https:// doi.org/10.3390/su10030849

NIANG I, RUPPEL O, ABDRABO M, ESSEL A, LENNARD C, PADGHAM J and URQUHART P (2014) Africa. In: Barros V, Field C, Dokken D, Mastrandrea M, Mach K, Bilir T, Chatterjee M, Ebi K, Estrada Y, Genova R, Girma B, Kissel E, Levy A, MacCracken S, Mastrandrea P and White LL (eds), Climate Change 2014: Impacts, Adaptation, and Vulnerability. Part B: Regional Aspects. Contribution of Working Group II to the Fifth Assessment Report of the Intergovernmental Panel on Climate Change. Cambridge University Press, Cambridge and New York. 1199-1265.

PEACOCK T, WARD C and GAMBARELLI G (2007) Investment in agricultural water for poverty reduction and economic growth in sub-Saharan Africa. Synthesis Report. World Bank, Washington DC, USA.

SADC (Southern African Development Community) (2003) Regional Indicative Strategic Development Plan (RISDP). SADC Secretariat, Gaborone.

SADC (Southern African Development Community) (2014) Regional

http://dx.doi.org/10.4314/wsa.v44i3.15

Available on website http://www.wrc.org.za

ISSN 1816-7950 (Online) = Water SA Vol. 44 No. 3 July 2018

Published under a Creative Commons Attribution Licence 
Agricultural Policy. SADC Secretariat, Gaborone.

SADC (Southern African Development Community) (2015) Revised Regional Indicative Strategic; Development Plan 2015-2020. SADC Secretariat, Gaborone.

SADC (Southern African Development Community) (2016) Outcomes of the ministerial workshop on food security and poverty reduction: towards a poverty free and food secure future. SADC Secretariat, Gaborone.

SADC (Southern African Development Community) (2016) Regional Huminitarian Response Monitoring. SADC Secretariat, Gaborone.

SIEBERT S and DÖLL P (2010) Quantifying blue and green virtual water contents in global crop production as well as potential production losses without irrigation. J. Hydrol. 384 (3-4) 198-217. https://doi.org/10.1016/j.jhydrol.2009.07.031

SVENDSEN M, EWING M and MSANGI S (2009) Measuring irrigation performance in Africa. International Food Policy
Research Institute (IFPRI), Washington DC.

TURRAL H, SVENDSEN M and FAURES JM (2010) Investing in irrigation: Reviewing the past and looking to the future. Agric. Water Manage. 97 (4) 551-560. https://doi.org/10.1016/j. agwat.2009.07.012

VAN SCHILFGAARDE J (1994) Irrigation-a blessing or a curse. Agric. Water Manage. 25 (3) 203-219. https://doi.org/10.1016/03783774(94)90061-2 https://doi.org/10.1016/j.foodpol.2011.09.001

WORLD BANK (2007) World Development Report 2008: Agriculture for Development. World Bank, Washington DC.

YOU L, RINGLER C, WOOD-SICHRA U, ROBERTSON R, WOOD S, ZHU T, NELSON G, GUO Z and SUN Y (2011) What is the irrigation potential for Africa? A combined biophysical and socioeconomic approach. Food Polic. 36 (6) 770-782. https://doi. org/10.1016/j.foodpol.2011.09.001 